\title{
Evaluation of the Role Of bla Genes in Beta Lactam and Methicillin Resistant Staphylococcus aureus
}

\author{
Sarah H. Ahmed ${ }^{(1) \#}$, Sahar T.M. Tolba ${ }^{(1)}$, Yehia A. El-Zawahry ${ }^{(2)}$ \\ ${ }^{(1)}$ Department of Microbiology, Faculty of Science -Ain-Shams University, Cairo, \\ Egypt; ${ }^{(2)}$ Department of Botany, Zagazig University, Zagazig, Egypt.
}

\begin{abstract}
$\mathbf{O}$ NE HUNDRED and nineteen clinical samples were isolated from patients admitted in different hospitals in El-Sharkia Governorate. Sixty six isolates were confirmed to be $S$. aureus. Susceptibility to different antimicrobial agents and Minimum inhibitory concentration tests showed that all the isolates were resistant to $\beta$-lactam antibiotics, $77.2 \%(\mathrm{n}=51)$ isolates were methicillin resistant $S$. aureus MRSA, while almost all the isolates were sensitive to vancomycin and tigecycline. Polymerase chain reaction (PCR) of mecA, encoding methicillin resistance, and blaZ, $\beta$-lactamase biosynthetic gene, revealed the coexistence of both genes in $56.8 \%(n=29 / 51)$ of the isolates. Meanwhile, $11.7 \%(n=6 / 51)$ of MRSA isolates phenotypically resistant to oxacillin were found to be mec $\mathrm{A}$. This data support the fact that the expression of bla genes enhanced the phenotypic expression of oxacillin resistance as a result of $\beta$-lactamase hyperproduction. On the other hand, $33 \%$ of MRSA $(n=17 / 51)$ were blaZ $^{-}$suggesting a mutation event in blaZ or the existence of an alternative mechanisms for $\beta$-lactam resistance that may compete with mecA gene.
\end{abstract}

Key words: Staphylococcus aureus, mecA, blaZ, MRSA, MIC- $\beta$-lactamase resistant MRSA.

\section{Introduction}

Staphylococcus aureus is an extraordinarily versatile pathogen that can survive under hostile external environmental conditions, colonize mucous membrane and skin and cause severe toxin-mediated diseases or severe invasive purulent infections in humans (Archer, 1998 and Lowy, 1998). It represents a progressive problem in hospitals for decades, in addition, the occurrence of community-acquired infections have been increasing (Tokajjan, 2014).

Many studies reported the prevalence of MRSA isolates in Egypt (Tolba et al., 2013; AbdelMaksoud et al., 2016 and Abdelsalam et al., 2017). Data from the European Antimicrobial Resistance Surveillance System (EARSS) showed that in more than one-third of countries the proportion remained $>25 \%$ (Johnson, 2011). In Ireland, MRSA has been endemic in hospitals since the 1980s and different strains have predominated at different time periods (Shore et al., 2005). The pandemic sequence type (ST)8 USA300 of MRSA is the dominant CA-MRSA clone in the United States (Uhlemann et al., 2014).
The severity of staphylococcal infections combined with feeble treatment is due to the specific suite of virulence and antibiotic resistance-associated genes (Paul et al., 2015). Most methicillin-resistant Staphylococcus aureus (MRSA) infections occur in people who have been in hospitals or other healthcare settings, such as nurseries and dialysis centers (David \& Daum, 2010 and Fukunaga et al., 2016). Staphylococcal resistance to beta-lactam antibiotics is mediated by either of two mechanisms: (i) Production of beta-lactamase and (ii) Production of an altered target penicillin-binding protein ( $\mathrm{PBP} 2 \mathrm{a})$ (Pantosi et al., 2007).

Methicillin resistant gene mecA is embedded in a large heterologous chromosomal cassette, the SCCmec element (Ito et al., 1999). MRSA strains carry upstream to the mecA gene $m e c \mathrm{I}-m e c \mathrm{R} 1$ encoding for a repressor and a sensor/inducer of the mecA expression, respectively. The mecA gene is present in a mec gene complex in SCCmec elements. Four classes of the mec gene complex (A-D) have been described which were differ in their genetic organization (Katayama et al., 2001 and Ito et al., 2004). The SCCmec types are listed on the SCCmec website by the International

"Corresponding author email: sarahscience51@yahoo.com

DOI: 10.21608/ejbo.2018.4221.1187

Edited by: Prof. Dr. Wael El-Sayed, Faculty of Science, Ain Shams University, Cairo, Egypt.

C2019 National Information and Documentation Center (NIDOC) 
Working Group on the Classification of SCC Elements (IWG-SCC) (http://www.sccmec. org/Pages/SCC_TypesEN.html). This genetic organization is similar to the beta-lactamase locus that encodes for penicillin-resistance only, and contains the structural gene (blaZ), a repressor (blaI) and a sensor/inducer (BlaR1) (Shore et al., 2011). There is a cross-talk between both regulatory systems, as each one alone is able to control the transcription of mecA and blaZ (Hackbarth \& Chambers, 1993). Based on the aforementioned, it has been postulated that full resistance to betalactamase of many contemporary MRSA clinical strains, implies a non-functional mecI-mecR1 regulatory system (Hiramatsu et al., 1992). The cross link between mec genes and bla genes are not yet resolved. PCR detection for both genes has been tested. This study aims to assess the role of blaZ in $\beta$ lactam resistant methicillin resistant S.aureus isolates.

\section{Materials and Methods}

\section{Bacterial isolates}

A total of 119 samples were recovered from patients with age ranged from 22-86 years old, suffering from severe infections in different body sites. Those patients were submitted to different hospitals in the period from September 2014 to September 2015. Samples were collected from wounds, blood, sputum, urine (Table 1). Swabs were streaked on the surface of blood agar, BairedParker and mannitol salt agar media for selective isolation of Staphylococcus aureus. The purified colonies were then checked microscopically using Gram-stain and biochemically using catalase and coagulase tests (Cheesbrough, 2000 and Ryan \& Ray, 2004).

\section{Antibiotic susceptibility test}

Antimicrobial resistance to twelve antibiotics was carried out by Kirby-Bauer disk diffusion method according to (Bauer, 1966). Muller Hinton plates were inoculated with bacterial suspensions of approximately $0.5 \mathrm{McF}$ arland. The antibiotic disks were placed on the agar surface and incubated at $37^{\circ} \mathrm{C}$ for $18-24 \mathrm{~h}$. Inhibition zone diameter $(\mathrm{mm})$ was measured as recommended by CLSI (2016). The antibiotics discs used in $\mu \mathrm{g}$ were azithromycin 15 , ampicillin 10 , ceftazidime 30 , cefotaxime 30 , vancomycin 30, oxacillin 1, erythromycin 15 , Doxycycline 30, imipenem 10, ciprofloxacin 5, ceftriaxone 30 .
Determination of minimum inhibitory
concentration
Minimum inhibitory concentration (MIC) for isolates that were phenotypically oxacillin resistant was evaluated using Vitek 2 card AST-GP67 (biomerieux, France) according to Kumar et al. (2013) and Bobenchik et al. (2014). Isolates were considered methicillin resistant Staphylococcus aureus if their MIC for oxacillin were $\geq 4 \mu \mathrm{g} / \mathrm{ml}$ (CLSI, 2016).

\section{Polymerase chain reaction}

DNA was extracted from the bacterial isolates according to Wilkening et al. (2013). PCR was carried out using the primer pair mecA1(5'GTAGAAATGACTGAACGTCCGATAA-3') corresponded to nucleotides 318 to 342 and mecA2 (5'-CCAATTCCACATTGTTTCGGTAA-3') complementary to nucleotides 603 to 627 for amplification of $310 \mathrm{bp}$ from the highly conserved region of the 2,456-bp mecA gene which encodes for the unique penicillin-binding protein associated with oxacillin resistance (Zhang et al., 2004). A second pair of primers was used for amplification of $533 \mathrm{bp}$ of blaZ gene blaZ1(5'-GAT AAG AGA TTT GCC TAT GC-3') corresponding to nucleotide position 165 to 186 and blaZ-2 (5'-GCA TAT GTT ATT GCT TGA CC-3') complementary to nucleotides 678 to 699 (Oliveira \& de Lencastre, 2011). A single colony was picked and boiled in $50 \mu$ of ultra pure water and then $1 \mu \mathrm{l}$ of the supernatant was used as DNA template. PCR was performed in a total volume of $25 \mu \mathrm{l}$ containing $20 \mathrm{\rho mol}$ of each primer, $12.5 \mu \mathrm{l}$ Bioline mastermix (Sigma) using $\mathrm{AB}$ applied Biosystem thermocycler 2720. The thermocycler protocol was $5 \mathrm{~min}$ at $95^{\circ} \mathrm{C}$ and then 30 cycles of denaturation at $95^{\circ} \mathrm{C}$ for $40 \mathrm{sec}$, annealing at $55^{\circ} \mathrm{C}$ for $1 \mathrm{~min}$ and extension at $72^{\circ} \mathrm{C}$ for $1 \mathrm{~min}$, post extension step at $72^{\circ} \mathrm{C}$ for $7 \mathrm{~min}$. The PCR products of mec $\mathrm{A}$ and blaZ genes were run in $1 \%$ agarose gel stained with $0.05 \%$ ethidium bromide.

\section{Results}

\section{Isolation of clinical isolates}

Clinical samples were collected from hospitalized patients with age range from 22 to 86 years old. Samples were collected from different sources, a total of 119 samples, $54 \%(n=65)$ of which collected from wounds, $22 \%(n=27)$ from blood, $12 \%(n=15)$ from sputum (Table 1$)$. The rest of the samples were collected from cerebrospinal fluid and urine. 
TABLE 1. Sources and numbers of $S$. aureus isolates.

\begin{tabular}{lcccccc}
\hline Source & $\begin{array}{c}\text { Total } \\
\text { number }\end{array}$ & $\begin{array}{c}\text { Age } \\
\text { range }\end{array}$ & $\begin{array}{c}\text { No. of } \\
\text { females }\end{array}$ & $\begin{array}{c}\text { No. of } \\
\text { males }\end{array}$ & $\begin{array}{c}\text { No. of S.aureus } \\
\text { isolates }\end{array}$ & Percentage (\%) \\
\hline Wound infections & 65 & $22-86$ & 18 & 18 & 36 & 54.54 \\
blood & 27 & $40-59$ & 10 & 11 & 21 & 31.82 \\
Sputum & 15 & $70-82$ & 2 & 3 & 5 & 7.57 \\
Cerebrospinal fluid & 3 & $55-63$ & 1 & 2 & 3 & 4.55 \\
Urine & 9 & $29-50$ & 0 & 1 & 1 & 1.52 \\
Total No. & 119 & 119 & 31 & 35 & 66 & 100 \\
\hline
\end{tabular}

Out of the 119 samples, 66 isolates were recovered and identified by conventional and biochemical methods as $S$. aureus. They produced black colonies surrounded by a clear zone on Baired-Parker agar media, yellow colonies on mannitol salt agar. They were catalase and coagulase positive. Most of the isolates were recovered from wound $54.5 \%(\mathrm{n}=36)$ and blood $31.8 \%(n=21)($ Table 1$)$.

\section{Antibiotic susceptibility and determination of} MIC

Antibiotic susceptibility test showed various degrees of resistance to the tested antibiotics. Out of $66 \mathrm{~S}$. aureus isolates, $77.2 \%(\mathrm{n}=51)$ isolates were oxacillin resistant $S$. aureus (ORSA) and $2.7 \%(\mathrm{n}=15)$ were oxacillin sensitive $S$. aureus (OSSA). All the isolates were $\beta$-lactam resistant, they exhibited $100 \%$ resistance to ampicillin and ceftazidime, while $77.2 \%$ were resistant to cefotaxime. The isolates were also carbapenem resistant $75.7 \%$ were resistant to meropenem while, $22 \%$ were resistant to imipenem, $68 \%$ were resistant to ceftriaxone, $44 \%$ were resistant to erythromycin. Only $13.6 \%$ were resistant to vancomycin as shown in Fig.1.

\section{Determination of minimum inhibitory concentrations}

The 51 oxacillin resistant isolates were selected for the study of MIC values against different antibiotics, using AST-GP67 card in Vitek 2 system. Isolates that were resistant to $\geq$ $4 \mu \mathrm{g} / \mathrm{ml}$ of oxacillin were regarded as oxacillin resistant $S$. aureus (ORSA) according to CLSI (2016). The results demonstrated that all the isolates were resistant to benzyl-penicillin $\geq 0.5 \mu \mathrm{g}$ / $\mathrm{ml}, 86.2 \%(\mathrm{n}=44)$ of isolates were resistant to $\geq 4 \mu \mathrm{g} / \mathrm{ml}$ oxacillin. In addition, $90 \%(\mathrm{n}=46)$ of the isolates were resistant to tetracycline as they showed resistant to $\geq 16 \mu \mathrm{g} / \mathrm{ml}$. Most of the isolates were sensitive to flouroquinones, only $15.7 \%$ ( $n=$ 8) were resistant to ciprofloxacin, $31.4 \%(n=$ 16) were resistant to levofloxacin, those isolates were able to grow at concentration $\geq 8 \mu \mathrm{g} / \mathrm{ml}$. Only $37 \%$ of the isolates $(n=19)$ were resistant to macrolides, they exhibited resistant to $\geq 8 \mu \mathrm{g} /$ $\mathrm{ml}$ to erythromycin and clindamycin. Most of the isolates were sensitive to vancomycin, only $11 \%$ $(\mathrm{n}=6)$ were resistant to $\geq 16 \mu \mathrm{g} / \mathrm{ml}$. Almost all the isolates were sensitive to tigecycline (Table 2).

\section{PCR detection of mecA and blaZ gene}

PCR detection of mecA and blaZ gene revealed single band of the right size (Fig. 2 a, b). The PCR data showed that most of ORSA isolates $88 \%(n=45)$ were found to harbor mecA gene. However, $11.7 \%(n=6)$ of the phenotypically oxacillin-resistant isolates were mecA: On the other hand, blaZ gene was detected in $66.6 \%(\mathrm{n}=$ 34 ) of the isolates (Table 2). Coexistence of both $m e c \mathrm{~A}$ and blaZ genes were recorded in $56.8 \%(\mathrm{n}=$ 29) of isolates (Table 2).

\section{Discussion}

Many bacteria have become resistant to most used antimicrobial agents. The high resistance rate was linked to the extensive antibiotic use and selective pressure (Davies \& Davies, 2010). Many studies reported the effect of sex, gender and the extent of exposure to microorganisms on the immune response (Oertelt-Prigione, 2012 and Fink \& Klein, 2015). In the present study, It was noticed that males could be more vulnerable to infections as the rate of infection in males $(53 \%)$ was higher than in females (46\%). 


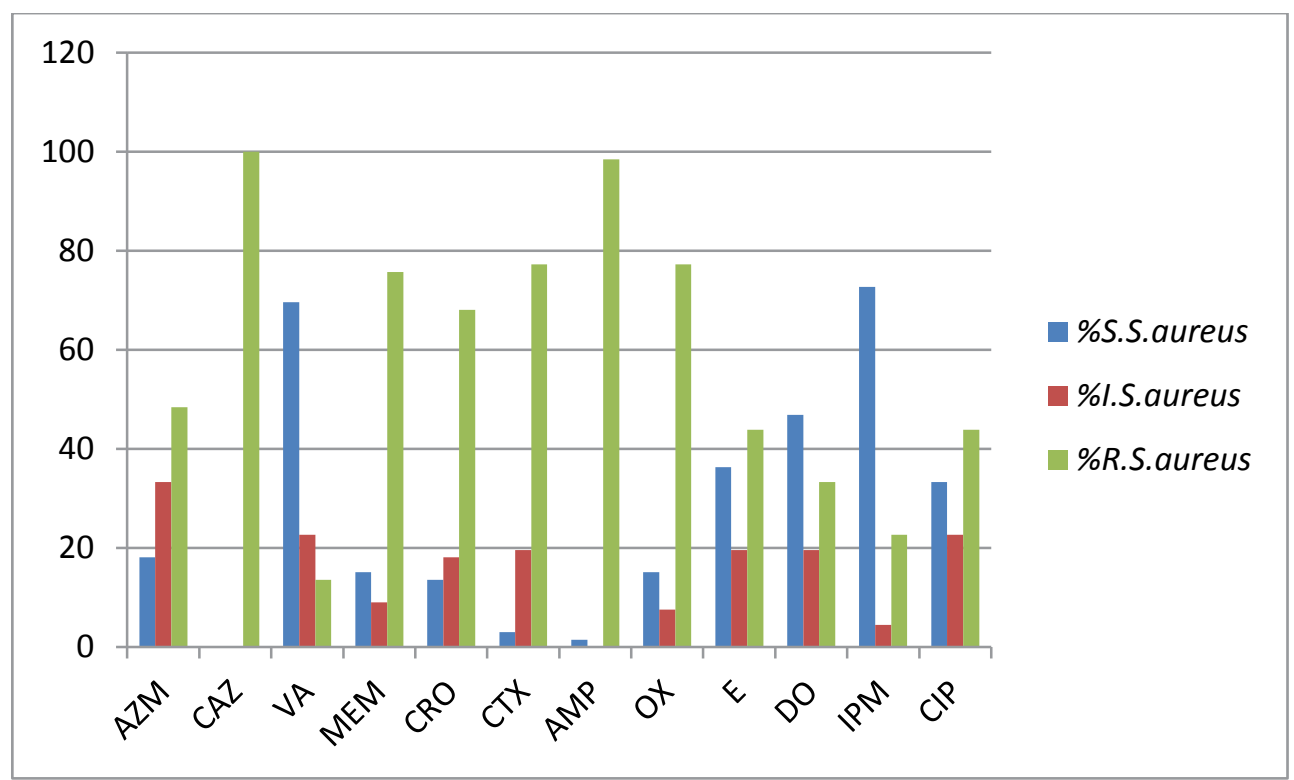

Fig. 1. Antibiotic resistance pattern of $S$. aureus isolates (AZM: Azithromycin, CAZ: Ceftazidime,VA: Vancomycin, MEM: Meropenem, CRO: Ceftriaxone CTX: Cefotaxime, AMP: Ampicillin, OX: Oxacillin, E: Erythromycin, DO: Doxacillin, IPM: Imipenem and CIP: Ciprofloxacin).

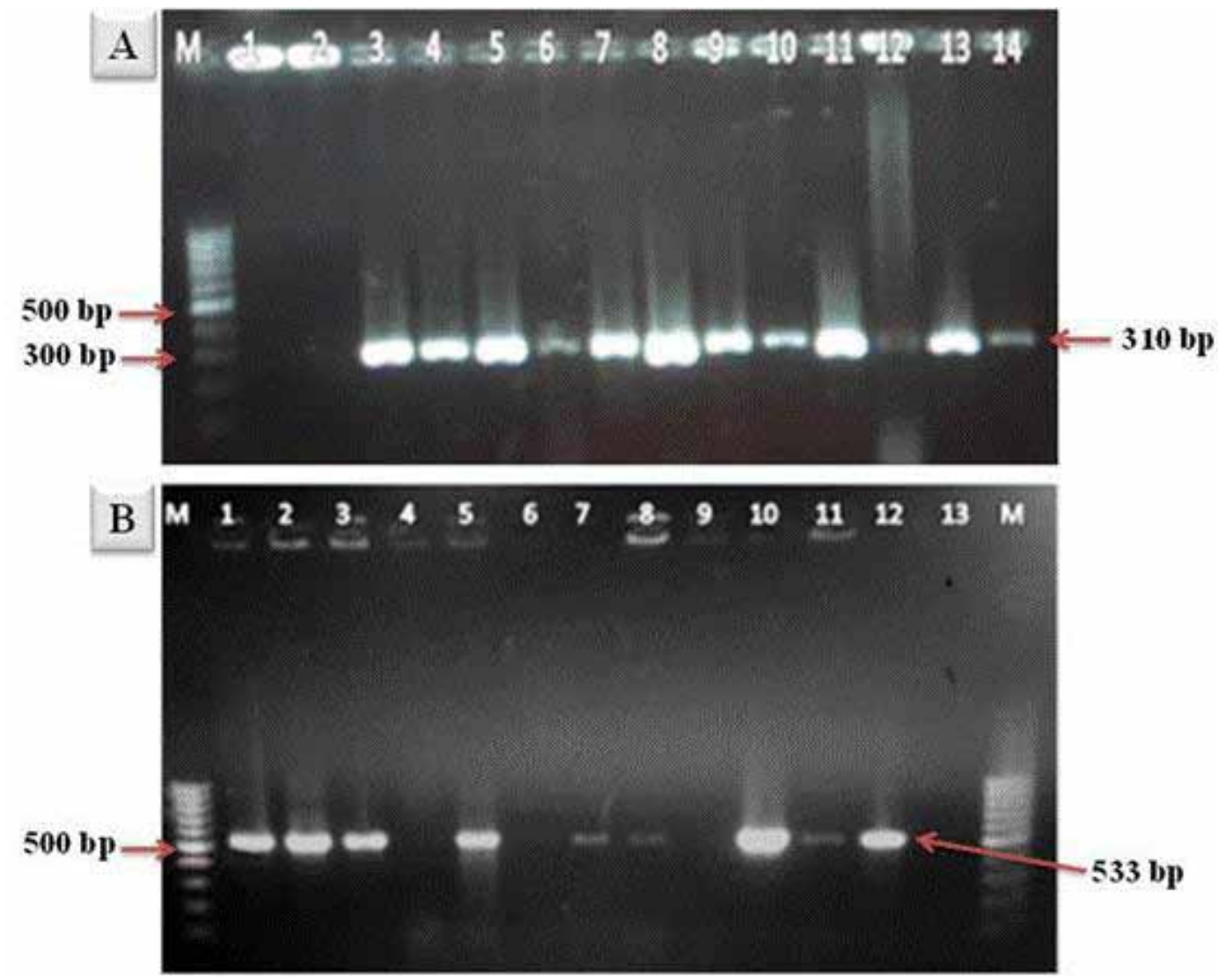

Fig. 2. Representative agarose gel photo of $P C R$ amplicons of $A$ - amplification of mecA gene, $M$ is $1 \mathrm{~kb}$ ladder, lane 1 is negative control, lanes 2-14 are amplicons of $m e c \mathrm{~A}$ gene from $S$. aureus isolates. B-amplification of blaZ gene. $M$ is $1 \mathrm{~kb}$ ladder, lanes 1-12 are amplicons of bla $\mathrm{Z}$ and lane 13 is negative control. 


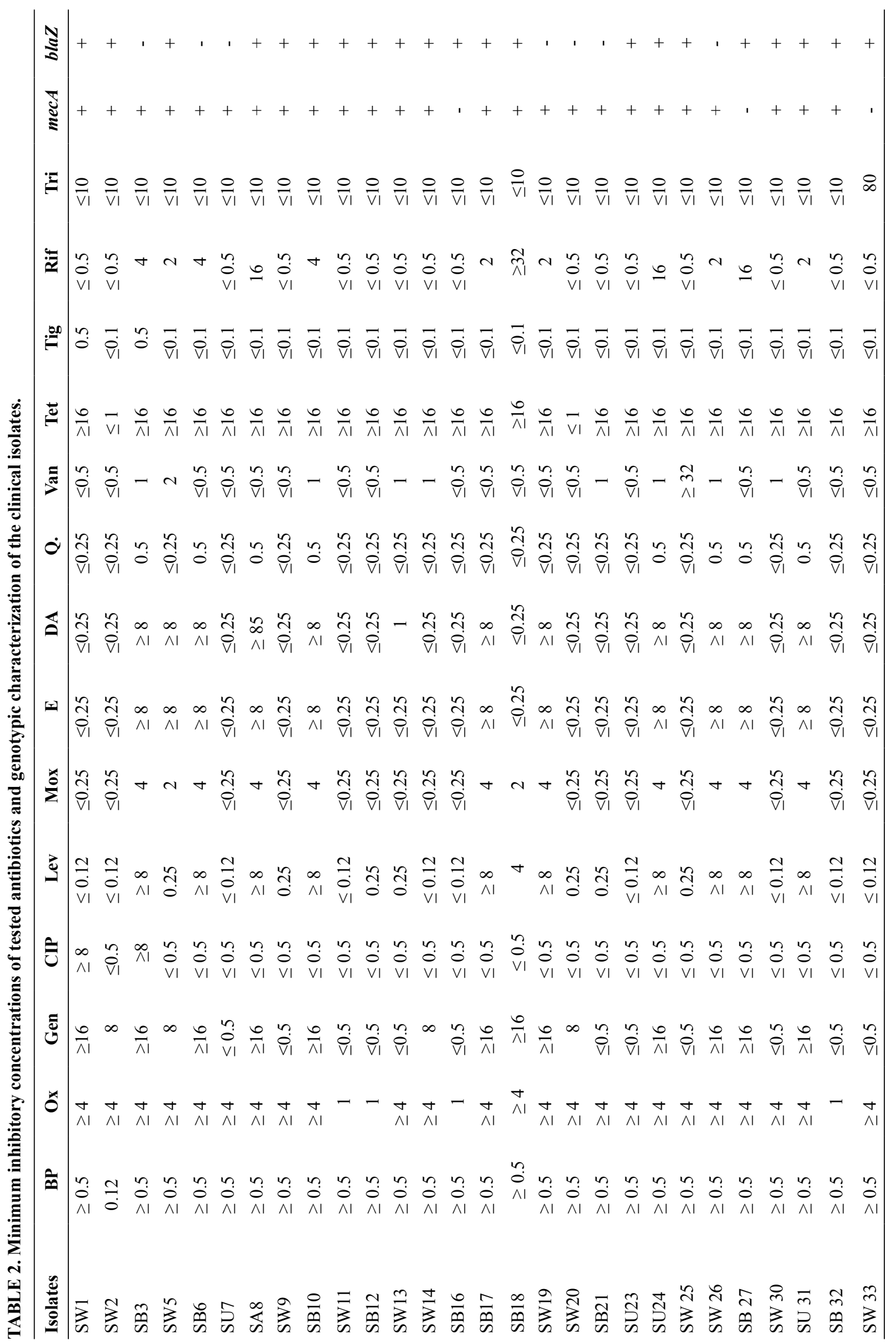




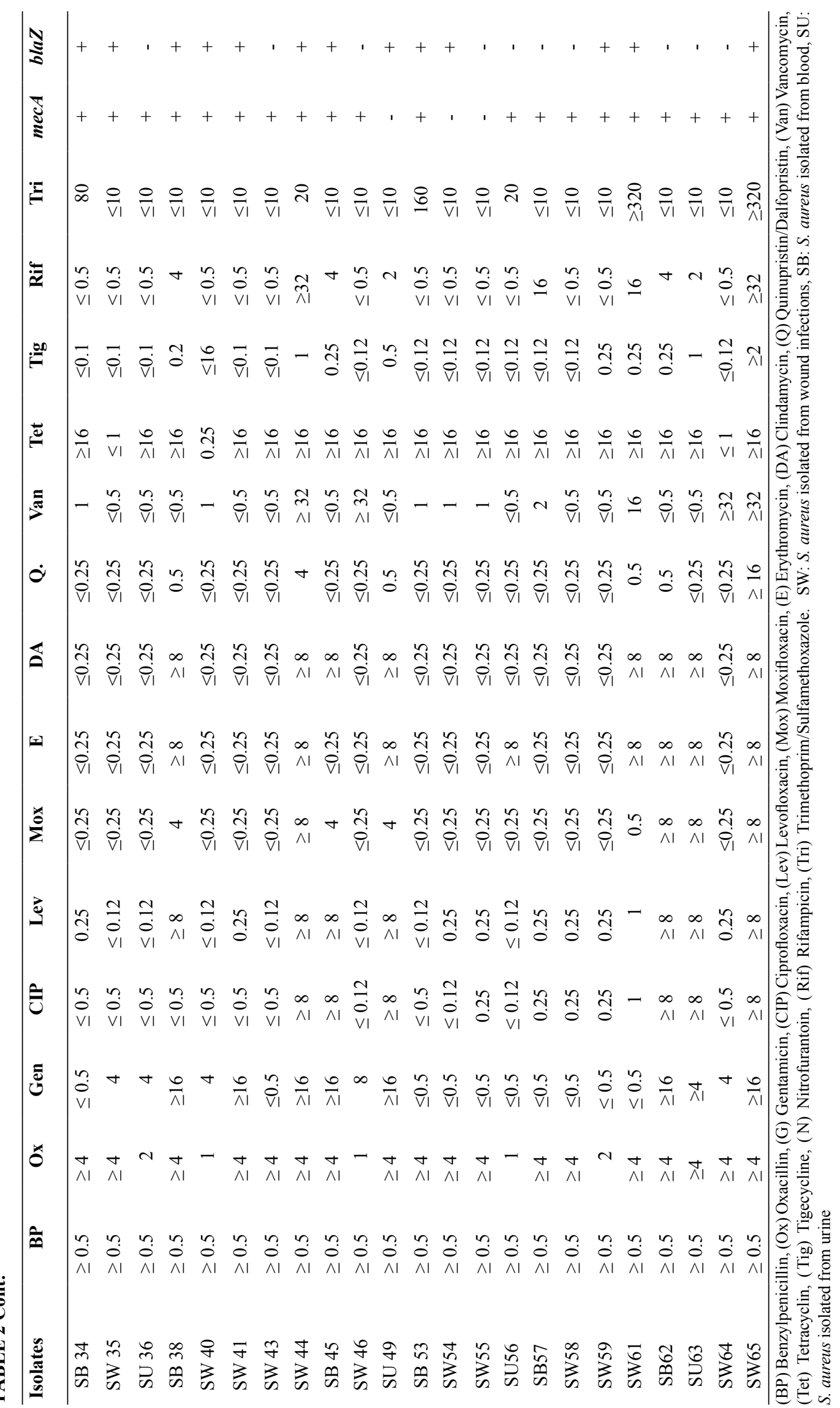

Egypt. J. Bot. 59, No.1 (2019) 
Most Staphylococcus aureus isolates associated with nosocomial infections have developed multidrug resistance and had relatively high MIC values to oxacillin and tetracycline, erythromycin and ciprofloxacin (Duin \& Paterson, 2016). Our results showed that high levels of resistance was detected against oxacillin, $\beta$-lactam and tetracycline however low level of resistance was recorded against macrolides and flouroquinones. In addition, most of the isolates were sensitive to vancomycin and tigecycline.

Marlowe \& Bankowski (2011) suggested that the use of molecular techniques in the detection of MRSA is essential for rapid diagnosis. Ostojić \& Hukić (2015) demonstrated a correlation between phenotypic and genotypic characteristics. Their results revealed that all MRSA isolates were $m e c \mathrm{~A}^{+}$, while Panda et al. (2016) stated that using conventional methods for detection of MRSA is more significant than detection with PCR. In the present study, $15.6 \%(n=8)$ isolates showed low level of resistance to oxacillin ( 1 or $2 \mu \mathrm{g} / \mathrm{ml})$ were found to harbor mecA gene, while four isolates that were resistant to $\geq 4 \mu \mathrm{g} / \mathrm{ml}$ oxacillin lacked mecA gene. This finding is in agreement with a study by Elhassan et al. (2015) who suggested low burden of the mecA gene in MRSA isolates. In addition, Wielders et al. (2002) found that 5\% of the phenotypically methicillin-resistant isolates did not carry mecA. This finding opens the door to search for other intrinsic factors that may compete with mecA gene in producing resistance phenomenon in regions with high prevalence of MRSA.

In most clinically hospitalized cases, $\beta$-lactam is the drug of choice. MRSA strains resistant to $\beta$-lactam antibiotics frequently harbor blaZ in addition to mecA (Munita et al., 2015). In our study, the coexistence of both resistance genes $m e c \mathrm{~A}$ and blaZ were recorded in only $56.8 \%$ of the tested $\beta$-lactam resistant MRSA isolates, while $17(33 \%)$ of the isolates were blaZ negative. It was also found that blaZ gene was present in 5 isolates that were mecA negative. Ba et al. (2014) identified four MRSA isolates that lacked mecA, but still resistant to penicillin-resistant $\beta$-lactam antibiotics.

Arêde et al. (2013) suggested that there is a cross-talk between the two regulatory systems, and it has been demonstrated that bla regulators stabilize the mecA acquisition. The preservation of
blaZ gene in MRSA isolates, even in the absence of $m e c A$, could be implicated as "a first-line defense" against $\beta$-lactams. Recent studies analyzed bla genes among $S$. aureus clonal types and found that a selective pressure has long played a role to keep the bacteria sustain the bla locus fully functional and improve its activity. However, most existing MRSA strains that still carry the $\beta$-lactamase locus along with the SCCmec element, begin to lose the bla genes. This could occur as a result of the poor fitness cost associated with the bla genes and the recent acquisition of mecA gene (Foster, 2017). It is also hypothetically possible that there is a link between bla genes to other positively selected genes (e. g., the cadmium resistance genes present in some $\beta$-lactamase plasmids). The bla locus enhances the stabilization and in vitro acquisition of $m e c \mathrm{~A}$, explicating the retention of a functional bla regulatory system. Moreover, regulation of $m e c \mathrm{~A}$, by bla regulatory system, mimics that of blaZ gene in an unknown manner Arêde et al (2013).

ELhassan et al. (2015) reported the complete absence of mecA gene as well as penicillin-binding protein in isolates which were phenotypically classified as MRSA suggesting that $\beta$-lactamase hyperproduction is the cause of this resistance pattern. In our study the absence of mecA and blaZ genes was detected in $2 \%$ of the isolates. Hence, the hypothesis that mecA absence could be compensated by mec $\mathrm{C}$ gene, a homologue of $m e c \mathrm{~A}$ gene within newly emerging and recently recognized cassette chromosome for methicillin resistance may be accepted (Paterson et al., 2014 and Lindgren et al., 2016).

\section{Conclusion}

The presence of $\beta$ lactamase resistant MRSA strains lacking mecA gene suggests that phenotypically resistant MRSA could be misdiagnosed using molecular methods alone and provides evidence of alternative mechanisms for $\beta$-lactam resistance in MRSA. Our results suggest the possibility of the existence of unidentified mechanism of regulation involved in the transcriptional control of mecA gene in MRSA strains which is contradictory to the idea that in most clinical MRSA strains mecA gene is under the control of the bla regulatory genes. Mutagenesis and gene expression studies of the bla genes are still needed to resolve the mechanism of $\beta$-lactam resistance in MRSA strains. 


\section{References}

Abdel-Maksoud, M., El-Shokry, M., Ismail, G., Hafez, S., El-Kholy, A., Attia, E. and Talaat, M. (2016)Methicillin-resistant Staphylococcus aureus recovered from healthcare- and communityassociated infections in Egypt. Int. J. Bacteriol. http://dx.doi.org/10.1155/2016/5751785.

Abdelsalam, N.M., Bakry, H.M., Bolbol, S.A., Abdelsalam, A.E. and Atef, D.M. (2017) Methicillin-resistant Staphylococcus aureus: An interventional study among health care workers of surgical ICU at zagazig university hospital, Egypt. EJOM. 41(1), 97-113.

Archer, G.L. (1998) Staphylococcus aureus: A wellarmed pathogen. Clin. Infect. Dis. 26(5), 1179-81.

Arêde, P., Ministro, J. and Oliveira, D.C. (2013) Redefining the role of the B-lactamase locus in methicillin-resistant Staphylococcus aureus: B-Lactamase regulators disrupt the MecI mediated strong repression on mec $\mathrm{A}$ and optimize the phenotypic expression of resistance in strains with constitutive mecA expression. J. Antimicrob. Agents Chemother. 57(7), 3037-3045.

Ba, X., Harrison, E.M., Edwards, G.F., Holden, M.G., Larsen, A.R., Petersen, A., Skov, R.L., Peacock, S.J., Parkhill, .J, Paterson, G.K. and Holmes, M.A. (2014) Novel mutations in penicillinbinding protein genes in clinical Staphylococcus aureus isolates that are methicillin resistant on susceptibility testing, but lack the mec gene. Journal of Antimicrobial Chemotherapy, 69(3), 594-597. DOI: 10.1093/jac/dkt418.

Bauer, A.W., Kirby, W.M., Sherries, J.C. and Truck, M. (1966) Antibiotic susceptibility testing by the standard single disk method. J. Clin. Pathol. 45, 493-496.

Bobenchik, A.M., Hindler, J.A., Giltner, C.L., Saeki, S. and Humphries, R.M. (2014) Performance of Vitek 2 for antimicrobial susceptibility testing of Staphylococcus spp.and Enterococcus spp. J. Clin. Microbiol. 52(2), 392-397.

Cheesbrough, M. (2000) "Microbiological Tests: District Laboatory Practice in Tropical Countries", Cemer, A. and Evan,G. (Ed.), pp. 1-226. Cambridge University Press, UK.
Clinical and Laboratory Standards Institute CLSI (2016) Performance standards for antimicrobial susceptibility testing; $18^{\text {th }} \quad$ Informational Supplement. M100-S 18 Wayne, PA.

David, M.Z. and Daum, R.S. (2010) Communityassociated methicillin- resistant Staphylococcus aureus: Epidemiology and clinical consequences of an emerging epidemic. Clin. Microbiol. Rev. 23(3), 616-687.

Davies, J. and Davies, D .(2010) Origins and evolution of antibiotic resistance. Microbiol. Mol. Biol. Rev. 74(3), 417-433.

Duin, V. and Paterson, D. (2016) Multidrug resistant bacteria in the community: Trends and lessons learned. Infect. Dis. Clin. North Am. 300(2), 377390.

Elhassan, M.M., Ozbak, H.A., Hemeg, H.A., Elmekki, M.A. and Ahmed, L.M. (2015) Absence of the mecA gene in methicillin resistant Staphylococcus aureus isolated from different clinical specimens in Shendi City, Sudan. BioMed. Research International. http://doi.org/10.1155/2015/895860

Fink, A.L. and Klein, S.L. (2015) Sex and gender impact immune responses to vaccines among the elderly. Int. Union Physiol. Sci. 30(6), 408-416.

Foster, T.J. (2017) Antibiotic resistance in Staphylococcus aureus. Current status and future prospects. FEMS. Microbiol. Rev. 41, 430-449.

Fukunaga, B., Sumida, W.K., Taira, D.A., Davis, J.W., and Seto, T.B. (2016) Hospital-acquired methicillin Staphylococcus aureus Bacteremia. Hawaii J. Med. Public Health, 75(10), 303-309.

Hackbarth, C.J. and Chambers, H.F. (1993) blaI and blaR 1 regulate beta-lactamase and PBP 2a production in methicillin-resistant Staphylococcus aureus. J. Antimocrob. Agents Chemother. 37(5), 1144-9.

Hiramatsu, K., Asada, K., Suzuki, E., Okonogi, K., and Yokota, T. (1992) Molecular cloning and nucleotidesequence determination of the regulator region of mecA gene in methicillin-resistant Staphylococcus aureus (MRSA). FEBS Letters, 298, 133-136.

Ito, T., Katayama, Y. and Hiramatsu, K. (1999) 
cloning and nucleotide sequence determination of the entire mec DNA of pre-methicillin-resistant Staphylococcus aureus N315. J. Antimocrob. Agents Chemother. 43(6), 1449-58.

Ito, T., Ma, X., Takeuchi, F., Okuma, K., Yuzawa, H. and Hiramatsu, K. (2004) Novel type V staphylococcal cassette chromosome mec driven by a novel cassette chromosome recombinase, ccrC. Antimicrob. Agents Chemother. 48, 2637-2651.

Johnson, A.P. (2011) Methicillin-resistant Staphylococcus aureus: The European landscape. J. Antimicrob. Chemother. 66(4), 43-48.

Katayama, Y., Ito, T. and Hiramatsu, K. (2001) Genetic organization of the chromosome region surrounding mecA in clinical staphylococcal strains: Role of IS431-mediated mecI deletion in expression of resistance in mecA-carrying, low-level methicillinresistant Staphylococcus haemolyticus. Antimicrob. Agents Chemother. 45, 1955-1963.

Kumar, V.A., Steffy, K., Chatterjee, M., Augumar, M., Dinesh, K.R., Manoharan, A., Karim, S. and Biswas, R. (2013) Detection of oxacillin-susceptible mecApositive Staphylococcus aureus isolated by use of chromogenic medium MRSA ID. J. Clin. Microbiol. 51(1), 318-319.

Lindgren, A.K., Gustafsson, E., Petersson, A.C. and Melander, E. (2016) Methicillin-resistant Staphylococcus aureus with mecC: A description of 45 human cases in southern Sweden. Eur. J. Clin. Microbiol. Infect. Dis. 35(6), 971-24.

Lowy, F.D. (1998) Staphylococcus aureus infections. $N$. Eng. J. Med. 339(8), 520-32.

Marlowe, E.M. and Bankowski, M.J. (2011) Conventional and molecular methods for the detection of methicillin-resistant Staphylococcus aureus. J. Clin. Microbiol. 49(9 Suppl), S53-S56.

Munita, J.M., Bayer, A.S. and Arias, C.A. (2015) Evolving resistance among Gram-positive pathogens. Clin Infect. Dis. 61(Suppl 2), S48-57.

Oertelt-Prigione, S. (2012) The influence of sex and gender on the immune response. Autoimmun Rev. 11(6-7), A479-85. DOI: 10.1016/j. autrev.2011.11.022. Epub 2011 Dec 3.

Oliveira, D.C. and de Lencastre, H. (2011) Methicillin- resistance in Staphylococcus aureus is not affected by the overexpression in trans of the mecA gene repressor: A surprising observation. PLoS ONE, 6(8), e23287.

Ostojić, M. and Hukić, M. (2015) Genotypic and phenotypic characteristics of methicillin-resistant Staphylococcus aureus (MRSA) strains, isolated on three different geography locations. Bosnian J. Basic Medical Sci. 15(3), 48-56. http://doi. org/10.17305/bjbms.2015.402.

Panda, R.K., Mahapatra, A., Mallick, B. and Chayani, N. (2016) Evaluation of genotypic and phenotypic methods for detection of methicillin resistant Staphylococcus aureus in a tertiary care hospital of Eastern Odisha. J. Clin. Diagnost.Research :JCDR, 10(2), DC19-DC21.

Pantosi, A., Sanchini, A. and Monaco, M. (2007) Mechanisms of antibiotic resistance in Staphylococcus aureus. Future Microbiol. 2(3), 323-34.

Paterson, G.K., Harrison, E.M. and Holmes, M.A. (2014) The emergence of mecC methicillinresistant Staphylococcus aureus. Trends Microbiol. 22(1), 42-47.

Paul, M., Bishara, J., Yahav, D., Goldberg, E., Neuberger, A., Ghanem-Zoubi, N., Dickstein, Y., Nseir, W., Dan, M. and Leibovici, L. (2015) Trimethoprim- sulfamethoxazole vancomycin for severe infections caused by methicillin-resistant Staphylocopccus aureus: Randomized controlled trial. B.M.J. 14(350), h2219. DOI: 10.1136/bmj. h2219.

Ryan, K.J. and Ray, C.G. (2004) "Sherris Medical Microbiology" (4 $4^{\text {th }}$ ed.). McGraw Hill. ISBN 0-83858529-9.

Shore, A.C., Rossney, A.S., Keane, C.T., Enright, M.C. and Coleman, D.C. (2005) Seven novel variants of the staphylococcal chromosomal cassette mec in methicillin-resistant Staphylococcus aureus isolates from Ireland. Antimicrob. Agents Chemother. 49, 2070-2083.

Shore, A.C., Deasy, E.C., Slickers, P., Brennan, G., O'Connell, B., Monecke, S., Ehricht, R. and Coleman (2011) Detection of staphylococcal cassette chromosome mec, type XI carrying highly divergent $m e c \mathrm{~A}, m e c \mathrm{I}, m e c \mathrm{R} 1$, blaZ, and ccr genes in human 
clinical isolates of clonal complex 130 methicillinresistant Staphylococcus aureus. J. Antimicrob. Agents Chemother. 55(8), 3765-3773.

Tokajjan, S. (2014) New epidemiology of Staphylococcus aureus infections in the Middle East. Clin. Microbiol. Infect. 20(7), 624-8.

Tolba, S.T.M., El-Shatoury, E.H., Abdallah, N.A. and Mahmoud, S.A. (2013) Phenotypic and genotypic characterisation of methicillin and vancomycin resistant staphylococci. African J. Microbiol. Res. 7(47), 5324-5329.

Uhlemann, A.C., Dordel, J., Knox, J.R., Raven, K.E., Parkhill, J., Holden, M.T., Peacock, S.J. and Lowy, F.D. (2014) Molecular tracing of the emergence, diversification, and transmission of $S$. aureus sequence type 8 in a New York community. Proc. Natl. Acad. Sci. 111(18), 6738-43.

Wielders, C.L.C., Fluit, A.C., Brisse, S., Verhoef, J. and Schmitz, F.J. (2002) mecA gene is widely disseminated in Staphylococcus aureus population. J. Clinic. Microbiology, 40(11), 970-3975. http://doi. org/10.1128/JCM.40.11.3970-3975.2002.

Wilkening, S., Pelechano, V., Jarvelin, A., Tekkedil, M.M., Anders, S., Benes, V. and Steinmetz, L.M. (2013) An efficient method for genome-wide polyadenylation site mapping and RNA quantification. Nucleic Acids Research, 41(5), e65.

Zhang, K., Sparling, J., Chow, B.L., Elsayed, S., Hussain, Z., Church, D.L., Gregson, D.B., Louie, T. and Conly, J.M. (2004) New quadriplex PCR assay for detection of methicillin and mupirocin resistance and simultaneous discrimination of Staphylococcus aureus from coagulase-negative staphylococci. $J$. Clinic. Microbiol. 42, 4947-4955.

(Received 28/6/2018; accepted $7 / 9 / 2018$

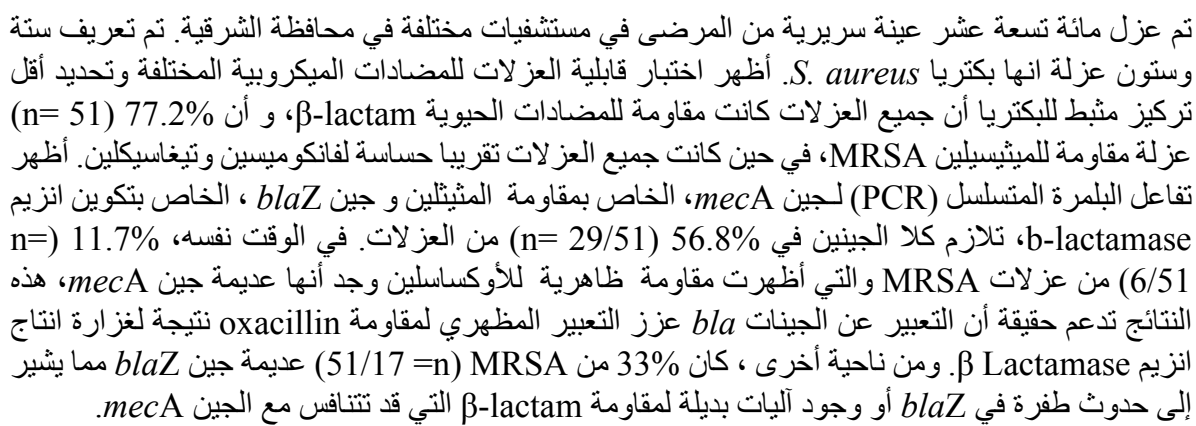

